\title{
Relationships between immunoglobulin and fat-soluble vitamins in colostrum of Japanese Black multiparous cows.
}

\section{AUTHOR(S):}

Wang, Mengdong; Ikeda, Shuntaro; Yoshioka, Hidetugu; Nagase, Hiroshi; Kitamura, Shoko; Itoyama, Erina; Murakami, Hiroaki; Sugimoto, Miki; Kume, Shinichi

\section{CITATION:}

Wang, Mengdong ... [et al]. Relationships between immunoglobulin and fat-soluble vitamins in colostrum of Japanese Black multiparous cows.. Animal science journal 2014, 86(7): 673-678

\section{ISSUE DATE:}

2014-12-11

URL:

http://hdl.handle.net/2433/201835

\section{RIGHT:}

This is the peer reviewed version of the following article: Wang, M., Ikeda, S., Yoshioka, H., Nagase, H., Kitamura, S., Itoyama, E., Murakami, H., Sugimoto, M. and Kume, S. (2015), Relationships between immunoglobulin and fat-soluble vitamins in colostrum of Japanese Black multiparous cows. Animal Science Journal, 86: 673-678, which has been published in final form at http://dx.doi.org/10.1111/asj.12351. This article may be used for non-commercial purposes in accordance with Wiley Terms and Conditions for Self-Archiving.; The full-text file will be made open to the public on 11 December 2015 in accordance with publisher's 'Terms and Conditions for Self-Archiving'.; This is not the published version. Please cite only the published version.; この論文は出版社版でありません。引用の際には出版社版をご確認ご 利用ください。 
Relationships between immunoglobulin and fat-soluble vitamins in colostrum of Japanese Black multiparous cows

Mengdong WANG ${ }^{\mathrm{a}}$, Shuntaro IKEDA ${ }^{\mathrm{a}}$, Hidetugu YOSHIOKA ${ }^{\mathrm{b}}$, Hiroshi NAGASE ${ }^{\mathrm{b}}$,

${ }^{a}$ Graduate School of Agriculture, Kyoto University, Kyoto 606-8502, Japan

${ }^{b}$ Kyoto University Livestock Farm, Kyotanba 622-0203, Japan

Correspondence author: Shinichi Kume,

Graduate School of Agriculture, Kyoto University, Kitashirakawa Oiwake-cho, 


\section{ABSTRACT}

Data from 19 Japanese Black multiparous cows were collected to clarify the relationships among Immunoglobulin (Ig) G, IgA, $\beta$-carotene, vitamin A and $\alpha$-tocopherol contents in colostrum of cows in order to evaluate the role of fat-soluble vitamins on colostral IgG and

5 IgA production. Mean colostral IgG was $141 \mathrm{mg} / \mathrm{mL}$, ranging from 65 to $208 \mathrm{mg} / \mathrm{mL}$,

$6 \quad$ whereas mean colostral IgA was $8.7 \mathrm{mg} / \mathrm{mL}$, ranging from 1.0 to $34.6 \mathrm{mg} / \mathrm{mL}$. Colostral IgG

7 was increased with aging in multiparous cows. There were positive correlations between

8 colostral IgG and colostral vitamin A or colostral $\alpha$-tocopherol in cows, and the higher $9 \quad$ adjusted $R^{2}$ was obtained in the prediction model of colostral IgG from age and colostral

10 vitamin A. Colostral vitamin A was positively correlated with colostral $\beta$-carotene or colostral

$11 \alpha$-tocopherol in cows, but there were no relationships between colostral IgA and colostral IgG or colostral fat-soluble vitamins. These results indicate that fat-soluble vitamin contents in colostrum of cows may be changed in similar patterns and high colostral vitamin A is related 14 with high colostral IgG. 


\section{INTRODUCTION}

Mortality and morbidity of neonates continue to be major problems in calves, and their most common disease is diarrhea, which can cause growth retardation and death of calves. Successful neonatal health depends on many factors related to management and nutrition, but the improvement of immune system is required for preventing diarrhea. Passive immunity is critical to the survival and health of neonates, and colostrum is a source of nutrients and immune components for neonatal calves (Blum 2006).

Immunoglobulin (Ig) antibodies are main immune components in colostrum and the most abundant Ig in bovine colostrum is IgG (Stelwagen et al. 2009). Compared with colostral IgG, colostral IgA in cows is very low (Ishikawa et al 1992), but IgA is the most abundant Ig isotype in mucosal secretions and provides protection against microbial antigens at mucosal surfaces in guts (Fagarasan \& Honjo 2003; Mora \& von Andrian 2009). In the previous study (Yasumatsuya et al. 2012), feeding whey protein is useful to enhance mucosal IgA induction in calves, because feeding whey protein increased fecal IgA in Japanese Black calves after 14 days of age.

The transfer of passive immunity reduces the incidence and severity of scours in calves, although the disease resistance acquired from colostral Ig is only temporary and scours are common at 5 days to 3 weeks of age in calves (Quigley \& Drewry 1998). However, the improvement of colostral IgG and IgA in Japanese Black cows is needed for the appropriate calf health and immune system, because the lower transfer of IgG and IgA from colostrum to neonatal calves was found in Japanese Black calves at 2 days of age (Yasumatsuya et al. 2013).

Supplemental vitamin A and $\beta$-carotene enhance the immune system in neonates (Chew \& Park 2004; Rühl 2007), and vitamin E deficiency is associated with the impairments in the 
cellular and humoral immunity (Maydani et al. 2005; Webb \& Villamor 2007). High-quality silages contain large amounts of $\beta$-carotene and vitamin $E$, and $\beta$-carotene is converted to vitamin A by enzymes in the intestinal mucosa of cows (Johansson et al. 2014). Dietary levels of $\beta$-carotene and vitamin A affected not only colostral vitamin contents in cows but also vitamin status in newborn calves (Kume \& Toharmat 2001). Supplemental $\beta$-carotene drastically increased serum $\beta$-carotene in Japanese Black calves (Nishiyama et al. 2011a), but $\beta$-carotene deficient calves were found to have a higher incidence of diarrhea in the first week of life (Kume \& Toharmat 2001). Supplemental $\beta$-carotene in maternal mice during pregnancy and lactation increased the numbers of IgA antibody-secreting cells (ASC) in the mammary glands of lactating mice and enhanced IgA transfer from maternal milk to neonatal mice (Nishiyama et al. 2011a,b). These results indicate that supplemental fat-soluble vitamins have been expected to improve colostral Ig in cows and health status in neonatal calves. However, it is not clear whether colostral IgG and IgA in cows were affected by dietary fat-soluble vitamins. cows in order to evaluate the role of fat-soluble vitamins on colostral IgG and IgA production.

\section{MATERIALS AND METHODS}

"Regulation on Animal Experimentation at Kyoto University” (Animal Research Committee, Kyoto University, revised 2007). Data from 19 Japanese Black multiparous cows kept at

\section{Animals and diets}

This research was approved by the guide for the care and use of cows in accordance with Kyoto University Livestock Farm (Kyotanba, Japan) were collected from August 2013 to 
February 2014. The parity of cows at parturition was $4.9 \pm 2.0$ (mean \pm SD), ranging from 2 to 9 , and body weight of cows at 10 days before the expected calving date was $575 \pm 46 \mathrm{~kg}$ (mean $\pm \mathrm{SD}$ ), ranging from 478 to $650 \mathrm{~kg}$. The cows were managed in paddocks during the dry period and an individual calving pen from 10 days before the expected calving date to parturition.

The cows were given $2 \mathrm{~kg} /$ day of wheat bran and appropriate amounts of Italian ryegrass or Sudangrass round baled silages to meet the TDN requirements of breeding cows (Agriculture, Forestry, and Fisheries Research Council Secretariat 2008), but synthetic vitamins did not offer to the cows. Italian ryegrass silages were produced from the first, second and third cuttings in 2012 and the first cutting in 2013, and Sudangrass silages were produced from the first and second cuttings in 2012. The wheat bran contained $0.07 \mathrm{mg} / \mathrm{kg}$ $\beta$-carotene and $31.3 \mathrm{mg} / \mathrm{kg} \alpha$-tocopherol, but vitamin contents in silages were not determined.

\section{Sample collection and analyses}

Body weights of calves were measured at birth. Samples of colostrum were taken from each udder of the cows by hand approximately within $1 \mathrm{~h}$ after parturition, and $100 \mathrm{~mL}$ colostrum were stored at $-20^{\circ} \mathrm{C}$ for chemical analyses.

The immunoassay of colostral IgG and IgA was determined as previously described (Nishiyama et al. 2011a; Yasumatsuya et al. 2013). Colostral IgG and IgA contents were measured using the Bovine IgG and IgA ELISA Quantitation Kit (Bethyl Laboratories, Montgomery, USA) and ELISA Starter Accessory Package (Bethyl Laboratories) according to the manufacturer's instructions, respectively.

Colostral $\beta$-carotene, vitamin A and $\alpha$-tocopherol were determined by high-performance liquid chromatography (HPLC). Briefly, 50-300 $\mu \mathrm{L}$ colostrum were homogenized in $3 \mathrm{~mL}$ of ethanol with 1 (vitamin A) or 6 ( $\beta$-carotene and $\alpha$-tocopherol) \% pyrogallol. The homogenate 
was mixed with $300 \mu \mathrm{L}$ of $60 \% \mathrm{KOH}$ and heated for saponification. After the addition of 3 $\mathrm{mL}$ of water, vitamins were extracted with $6 \mathrm{~mL}$ of $\mathrm{n}$-hexane and the extract was evaporated to dryness. The residue was dissolved in $150-500 \mu \mathrm{L}$ of ethanol/chloroform (19:1) solution and $20 \mu \mathrm{L}$ of the sample was subjected to HPLC equipped with Shimadzu (Kyoto, Japan) LC-10 AT pump and SPD-10A UV-VIS detector set at 480 ( $\beta$-carotene), 325 (vitamin A), and 292 ( $\alpha$-tocopherol) nm absorbance, respectively. The combinations of mobile phase, column, and column temperature were methanol:tetrahydrofuran:water(94:5:1 v/v)/Vydac 201TP54 (Grace, Columbia, MD, USA)/21-24 ${ }^{\circ} \mathrm{C}$ for $\beta$-carotene, methanol:water(92:8)/Shim-pack CLC-ODS(M) (Shimadzu) $/ 40^{\circ} \mathrm{C}$ for vitamin A, and methanol(100)/Shim-pack CLC-ODS(M) $/ 40^{\circ} \mathrm{C}$ for $\alpha$-tocopherol, respectively. The flow rate of mobile phase was 0.8 $\mathrm{mL} / \mathrm{min}$.

\section{Statistics} were examined by correlation and regression analyses of Statistical Analysis Systems (SAS 1997). Significance was declared at $P<0.05$.

\section{RESULTS} cows and the health status of their calves was good at birth. The birth weight of calves was $34.3 \pm 3.8 \mathrm{~kg}$ (mean $\pm \mathrm{SD}$ ), ranging from 28.0 to $41.0 \mathrm{~kg}$, and the calf birth weight was positively correlated $(r=0.59 ; P<0.01)$ with the gestation length of dams.

Mean colostral IgG in cows was $141 \mathrm{mg} / \mathrm{mL}$, ranging from 65 to $208 \mathrm{mg} / \mathrm{mL}$, whereas mean colostral IgA was $8.7 \mathrm{mg} / \mathrm{mL}$, ranging from 1.0 to $34.6 \mathrm{mg} / \mathrm{mL}$ (Table 1). Colostral IgG 
was positively correlated $(P<0.01)$ with the age of cows, but colostral IgG was not correlated with the gestation length. There were positive correlations between colostral IgG and colostral vitamin A $(P<0.01)$ or colostral $\alpha$-tocopherol $(P<0.05)$ in cows, but there were no relationships between colostral IgG and colostral IgA or colostral $\beta$-carotene (Fig. 1). The regression equations of age $\left(\mathrm{X}_{\mathrm{Age}}\right)$, colostral vitamin $\mathrm{A}\left(\mathrm{X}_{\mathrm{VA}}\right)$ and colostral $\alpha$-tocopherol $\left(\mathrm{X}_{\mathrm{VE}}\right)$ on colostral IgG (Y $\left.\mathrm{Y}_{\mathrm{IG}}\right)$ were as follows.

$$
\begin{aligned}
& \mathrm{Y}_{\mathrm{IG}}=0.928( \pm 0.245)^{* *} \mathrm{X}_{\text {Age }}+73.6( \pm 18.7)^{* *}\left(R^{2}=0.43,{ }^{* *} P<0.01\right) \\
& \mathrm{Y}_{\mathrm{IG}}=0.082( \pm 0.023)^{* *} \mathrm{X}_{\mathrm{VA}}+101( \pm 12)^{* * *}\left(R^{2}=0.40,{ }^{* *} P<0.01,{ }^{* * *} P<0.001\right) \\
& \mathrm{Y}_{\mathrm{IG}}=0.031( \pm 0.012)^{*} \mathrm{X}_{\mathrm{VE}}+111( \pm 13)^{* * *}\left(R^{2}=0.24,{ }^{*} P<0.05,{ }^{* * *} P<0.001\right)
\end{aligned}
$$

There were no relationships between colostral IgA and fat-soluble vitamins in cows (Fig. 2). Colostral $\beta$-carotene was positively correlated with colostral vitamin $A(r=0.69 ; P<0.001)$ and colostral $\alpha$-tocopherol $(r=0.63 ; P<0.01)$, and colostral vitamin A was positively correlated $(r=0.78 ; P<0.001)$ with colostral $\alpha$-tocopherol. The regression equations of colostral $\beta$-carotene $\left(\mathrm{X}_{\mathrm{BC}}\right)$ on vitamin $\mathrm{A}\left(\mathrm{Y}_{\mathrm{VA}}\right)$ and colostral $\alpha$-tocopherol $\left(\mathrm{Y}_{\mathrm{VE}}\right)$ and the regression equation of colostral vitamin $\mathrm{A}\left(\mathrm{X}_{\mathrm{VA}}\right)$ on colostral $\alpha$-tocopherol $\left(\mathrm{Y}_{\mathrm{VE}}\right)$ were as follows.

$$
\begin{aligned}
& \mathrm{Y}_{\mathrm{VA}}=3.23( \pm 0.82)^{* * *} \mathrm{X}_{\mathrm{BC}}+85( \pm 112)\left(R^{2}=0.45,{ }^{* * *} P<0.001\right) \\
& \mathrm{Y}_{\mathrm{VE}}=6.33( \pm 1.87)^{* *} \mathrm{X}_{\mathrm{BC}}+168( \pm 256)\left(R^{2}=0.37,{ }^{* *} P<0.01\right) \\
& Y_{\mathrm{VE}}=1.68( \pm 0.32)^{* * *} \mathrm{X}_{\mathrm{VA}}+141( \pm 177)\left(R^{2}=0.59,{ }^{* * *} P<0.001\right)
\end{aligned}
$$

There was no relationship between colostral vitamin A and age of cows, but a highly significant relationship was obtained between colostral IgG ( $\left.\mathrm{Y}_{\mathrm{IG}}\right)$ and age $\left(\mathrm{X}_{\text {Age }}\right)$ and colostral vitamin $\mathrm{A}\left(\mathrm{X}_{\mathrm{VA}}\right)$.

$$
\mathrm{Y}_{\mathrm{IG}}=0.664( \pm 0.232)^{* *} \mathrm{X}_{\mathrm{Age}}+0.056( \pm 0.021)^{* *} \mathrm{X}_{\mathrm{VA}}+65.1( \pm 16.3)^{* * *}\left(R^{2}=0.58,{ }^{* *} P<0.01\right.
$$<smiles>CP[Po](=O)O[Na]</smiles> 


\section{DISCUSSION}

2

Colostrum contains not only nutrients but also biologically active substances that are essential for proper calf nutrition and health (Blum 2006; Stelwagen et al. 2009). The importance of adequate consumption of high-quality colostrum for acquisition of optimal nutrition and passive immunity is widely recognised in neonatal calves (Quigley \& Drewry 1998; Stelwagen et al. 2009). The increased transfer of IgG and IgA from maternal milk to neonates is needed for maintaining normal health in calves, but serum IgG and IgA were not detectable in colostrum-deprived calves at less than 2 days of age (Nonnecke et al. 2012). Additionally, colostral IgG contents as well as colostral protein of primiparous cows were lower than those of multiparous cows (Devery-Pocius \& Larson 1983; Kume \& Tanabe 1993a). The bovine mammary gland plays an active role in regulating Ig concentrations in colostrum, and also immune factors in colostrum play an important role in the host defense of the mammary gland, because the mammary gland is very susceptible to infection (Stelwagen et al. 2009). In the present study, colostral IgG was increased with aging in Japanese Black multiparous cows. Thus, the aging in multiparous cows may be a factor altering colostral IgG owing to the protection of the mammary gland from pathogenic organisms.

The absorption of colostral Ig by neonatal calves is considered adequate when serum IgG concentrations exceed $10 \mathrm{mg} / \mathrm{mL}$, because the mortality rates of calves with serum $\operatorname{IgG}<10$ $\mathrm{mg} / \mathrm{mL}$ were over twice than those of calves with higher IgG contents (Quigley \& Drewry 1998). On the other hand, passive immune protection of the newborn gastrointestinal tract is dependent on an active process of IgA ASC accumulation in the lactating mammary glands of the mother, and IgA antibodies produced from IgA ASC in the mammary glands are secreted into milk (Morteau et al. 2008; Nishiyama et al. 2011b; Wang et al. 2013). Mean colostral IgG and IgA contents in Japanese Black cows in the present study agreed with those of the 

other report (Ishikawa et al. 1992), but colostral IgG and IgA varied widely and colostral IgG was not correlated with colostral IgA. In the previous study (Yasumatsuya et al. 2013), there was no relationship between serum IgG and fecal IgA in Japanese Black calves at 2 days of age. These results suggest that the improving methods on IgG and IgA production in colostrum are different in cows, although the adequate supply of IgG and IgA from colostrum is essential to gain sufficient passive immunity in neonatal calves.

The composition of colostrum varied with a number of factors, including individuality, breed, parity, prepartum diet and occurrence of mastitis, and the production and composition of colostrum varied with the uptake of nutrients by the mammary gland, which was influenced by mammary blood flow and utilization of nutrients in the mammary gland (Foley \& Otterby 1978). In basic dairy cow diets, provitamin A ( $\beta$-carotene) and vitamin E are mainly found in pasture and in grass and legume silages, but the contents were highly variable and synthetic vitamins are often supplemented in the diets (Johansson et al. 2014). As a result, colostral $\beta$-carotene in 46 Holstein cows was $169 \pm 85 \mu \mathrm{g} / \mathrm{dL}$ (mean $\pm \mathrm{SD}$ ), ranging from 17.8 to $342.9 \mu \mathrm{g} / \mathrm{dL}$, and colostral vitamin A was $122 \pm 77 \mu \mathrm{g} / \mathrm{dL}$ (mean $\pm \mathrm{SD}$ ), ranging from 32.9 to $450.0 \mu \mathrm{g} / \mathrm{dL}$ (Kume \& Toharmat 2001). Additionally, colostral $\beta$-carotene and vitamin A in Holstein multiparous cows were not affected by the parity, but colostral vitamin A in primiparous cows was high level (Kume \& Tamabe 1993b). The wide range of colostral $\beta$-carotene and vitamin $\mathrm{A}$ in dairy cows may be due to the variable dietary levels of $\beta$-carotene and vitamin A and their uptake by the mammary gland (Kume \& Tanabe 1993b; Kume \& Toharmat 2001). In the present study, $\beta$-carotene, vitamin A and $\alpha$-tocopherol contents in colostrum of Japanese Black multiparous cows varied widely, but highly positive correlations were obtained among $\beta$-carotene, vitamin $\mathrm{A}$ and $\alpha$-tocopherol contents in colostrum. Thus, $\beta$-carotene, vitamin A and $\alpha$-tocopherol contents in colostrum of cows may be changed in similar patterns owing to the quality of silages and their uptake by the 
mammary gland.

Several effects of carotenoids are thought to be mediated by their metabolism to vitamin A and subsequent mediation of retinoic acid (RA) receptor and retinoid $\mathrm{X}$ receptor response pathways (Rühl 2007). $\beta$-carotene supplementation is effective to enhance mucosal IgA induction in the jejunum or ileum in weanling mice, and these effects may be mainly due to the RA-mediated immune response (Nishida et al. 2014). In the present study, high colostral vitamin A was related with high colostral IgG in Japanese Black cows, and the higher adjusted $R^{2}$ was obtained in the prediction model of colostral IgG from age and colostral vitamin A. Additionally, colostral $\alpha$-tocopherol was positively correlated with colostral IgG, but colostral fat-soluble vitamins were not related with colostral IgA. These results indicate that feeding high-quality silages in pregnant cows has been expected to improve not only colostral fat-soluble vitamins but also colostral IgG contents. However, it is not clear whether supplemental vitamin A or $\beta$-carotene increases colostral IgG contents in cows owing to the RA-mediated immune response. Further study is needed to clarify the effects of fat-soluble vitamins on the passive immunity in calves, because a higher incidence of diarrhea occurred in the $\beta$-carotene deficient calves at 6 days of age (Kume \& Toharmat 2001).

\section{ACKNOWLEDGMENT}

The present study was supported in part by a grant from Ito Kinenzaidan (Tokyo, Japan).

\section{REFERENCES}

Agriculture, Forestry, and Fisheries Research Council Secretariat (AFFRCS). 2008. Japanese Feeding Standard for Beef Cattle. Chuouchikusankai, Tokyo, Japan.

Blum JW. 2006. Nutritional physiology of neonatal calves. Journal of Animal Physiology and 
Chew BP, Park JS. 2004. Carotenoid action on the immune response. Journal of Nutrition 134, 257S-261S.

Devery-Pocius JE, Larson BE. 1983. Age and previous lactations as factors in the amount of bovine colostral immunoglobulins. Journal of Dairy Science 66, 221-226.

Fagarasan S, Honjo T. 2003. Intestinal IgA synthesis: regulation of front-line body defences. Nature Immunology 3, 63-72.

Foley JA, Otterby DE. 1978. Availability, storage, treatment, composition, and feeding value of surplus colostrum: a review. Journal of Dairy Science 61, 1033-1060.

Ishikawa H, Serizawa S, Ahiko K, Asai Y, Seike N. 1992. Changes in the chemical composition of colostrum from Japanese Black cows. Animal Science and Technology (Japan) 63, 1153-1156.

Johansson B, Waller KP, Jensen SK, Lindqvist H, Nadeau E. 2014. Vitamins E and A and $\beta$-carotene status and health in organic dairy cows fed a diet without synthetic vitamins. Journal of Dairy Science 97, 1682-1692

Kume S, Tanabe S. 1993a. Effect of parity on colostral mineral concentrations of Holstein cows and value of colostrum as a mineral source for newborn calves. Journal of Dairy Science 76, 1654-1660.

Kume S, Tanabe S. 1993b. Effect of parity of Holstein cows on vitamin A and $\beta$-carotene concentrations of colostrum and calf serum. Animal Science and Technology (Japan) 64, 987-991.

Kume S, Toharmat T. 2001. Effect of colostral $\beta$-carotene and vitamin A on vitamin and health status of newborn calves. Livestock Production Science 68, 61-65.

Maydani SN, Han SN, Wu D. 2005. Vitamin E and immune response in the aged: molecular mechanisms and clinical implications. Immunological Reviews 205, 269-284. 
Mora JR, von Andrian UH. 2009. Role of retinoic acid in the imprinting of gut-homing IgA-secreting cells. Seminars in Immunology 21, 28-35.

Morteau O, Gerard C, Lu B, Ghiran S, Rits M, Fujiwara Y, Law Y, Distelhorst EM, Nielsen EM, Hill ED, Kwan R, Lazarus NH, Butcher EC, Wilson E. 2008. An indispensable role for the chemokine receptor CCR10 in IgA antibody-secreting cell accumulation. Journal of Immunoogyl 181, 6309-6315.

Nishida K, Sugimoto M, Ikeda S, Kume S. 2014. Effects of supplemental $\beta$-carotene on mucosal IgA induction in the jejunum and ileum of mice after weaning. British Journal of Nutrition 111, 247-253.

Nishiyama Y, Sugimoto M, Ikeda S, Kume S. 2011b. Supplemental $\beta$-carotene increases IgA-secreting cells in mammary gland and IgA transfer from milk to neonatal mice. British Journal of Nutrition 105, 24-30.

Nishiyama Y, Yasumatsuya K, Kasai K, Sakase M, Nishino O, Akaike M, Nagase T, Sugimoto M, Ikeda S, Kume S. 2011a. Effects of supplemental $\beta$-carotene with whey on IgA transfer from maternal milk and mucosal IgA induction in neonatal mice and calves. Livestock Science 137, 95-100.

Nonnecke BJ, Waters WR, Goff JP, Foote MR. 2012. Adaptive immunity in the colostrumdeprived calf: Response to early vaccination with Micobacterium bovis strain bacilli Calmette Guerin and ovaalbumin. Journal of Dairy Science 95, 221-239.

Quigley JD, Drewry JJ. 1998. Nutrient and immunity transfer from cow to calf pre- and postcalving. Journal of Dairy Science 81, 2779-2790.

Rühl R. 2007. Effects of dietary retinoids and carotenoids on immune development. Proceedings of the Nutrition Society 66, 458-469.

Statistical Analysis Systems (SAS). 1997. SAS/STAT software: Changes and Enhancement Through Release 6.12 SAS Institute, Cary, NC. 
Stelwagen K, Carpenter E, Haigh B, Hodgkinson A, Wheeler TT. 2009. Immune component of bovine colostrum and milk. Journal of Animal Science 87(Suppl.1), 3-9.

Wang M, Sugimoto M, Ikeda S, Kume S. 2013. Effects of coumestrol administration to maternal mice during pregnancy and lactation on IgA-secreting cells in mammary gland. Animal Science Journal 84, 322-327.

Webb AL, Villamor E. 2007. Update: effects of antioxidant and non-antioxidant vitamin supplementation on immune function. Nutrition Reviews 65, 181-217.

Yasumatsuya K, Kasai K, Yamanaka K, Sakase M, Nishino O, Akaike M, Mandokoro K, Nagase T, Kume S. 2012. Effects of feeding whey protein on growth rate and IgA induction in Japanese Black calves. Livestock Science 143, 210-213.

Yasumatsuya K, Kasai K, Yamanaka K, Sakase M, Nishino O, Akaike M, Mandokoro K, Kume S. 2013. Transfer of immunoglobulin G and immunoglobulin A to Japanese Black calves after birth. Nihon Chikusan Gakkaiho 84, 389-393 (In Japanese, with English abstract). 
Figure legends:

2

3 Figure 1 Relationships between colostral IgG and colostral IgA, vitamin A, $\alpha$-tocopherol or age in Japanese Black multiparous cows (n=19). IgA, Immunoglobulin A; IgG, Immunoglobulin G.

6

Figure 2 Relationships between colostral $\beta$-carotene and colostral vitamin A or $\alpha$-tocopherol and relationships between colostral vitamin A and colostral $\alpha$-tocopherol or IgA in Japanese Black multiparous cows (n=19). IgA, Immunoglobulin A.

10

11 
Table 1 Correlation between IgG, IgA and fat-soluble vitamins in colostrum of Japanese Black multiparous cows ( $\mathrm{n}=19)$.

\begin{tabular}{|c|c|c|c|c|c|c|}
\hline & \multirow[t]{2}{*}{ Mean } & \multirow[t]{2}{*}{ SD } & \multirow[t]{2}{*}{ Min. } & \multirow[t]{2}{*}{ Max. } & \multicolumn{2}{|l|}{ r } \\
\hline & & & & & IgG & IgA \\
\hline Age, months & 72.7 & 23.5 & 34.0 & 118.3 & $0.68 * *$ & 0.25 \\
\hline Gestation length, days & 287.7 & 4.6 & 277.0 & 296.0 & 0.32 & 0.37 \\
\hline \multicolumn{7}{|l|}{ Colostrum } \\
\hline$\beta$-carotene, $\mu \mathrm{g} / \mathrm{dL}$ & 125.7 & 56.0 & 40.0 & 221.0 & 0.35 & -0.07 \\
\hline Vitamin $\mathrm{A}, \quad \mu \mathrm{g} / \mathrm{dL}$ & 490.5 & 259.4 & 69.0 & 1096.0 & $0.66^{* *}$ & -0.01 \\
\hline$\alpha$-tocopherol, $\quad \mu \mathrm{g} / \mathrm{dL}$ & 963.2 & 554.3 & 117.0 & 2606.0 & $0.53 *$ & 0.17 \\
\hline IgA, mg/mL & 8.7 & 9.7 & 1.0 & 34.6 & 0.32 & - \\
\hline IgG, mg/mL & 140.9 & 32.2 & 65.0 & 208.0 & - & - \\
\hline
\end{tabular}

$* * P<0.01, * P<0.05$.

IgA, Immunoglobulin A; IgG, Immunoglobulin G. 

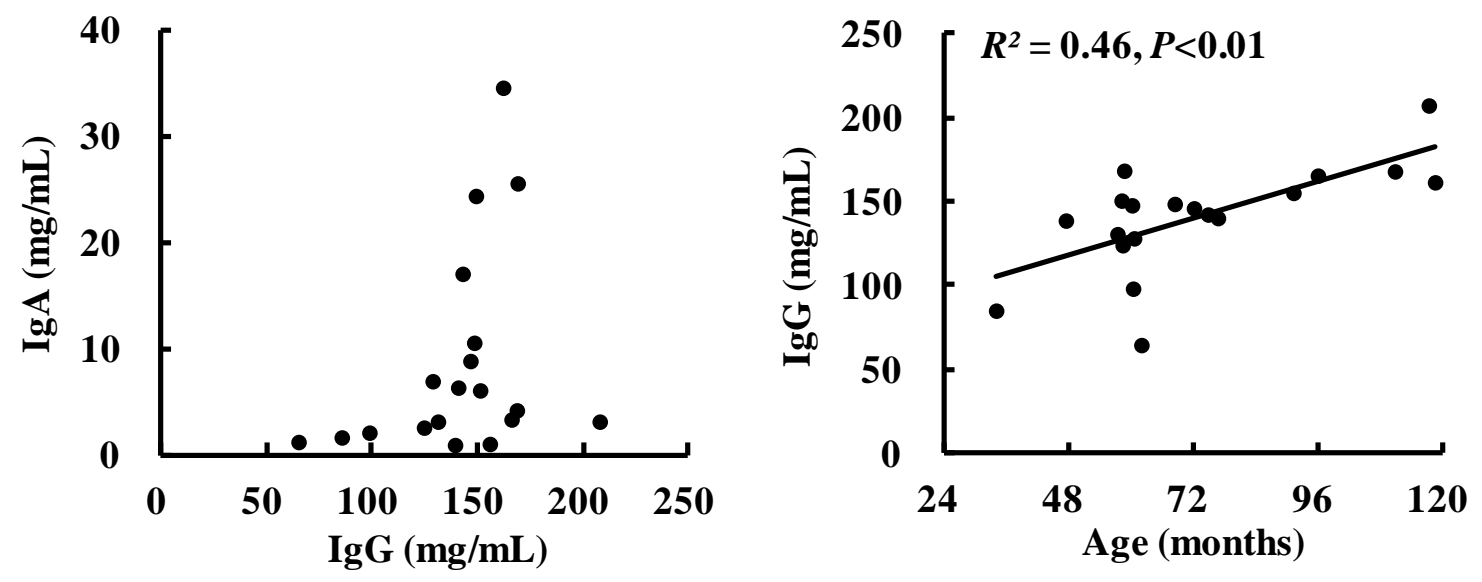

2
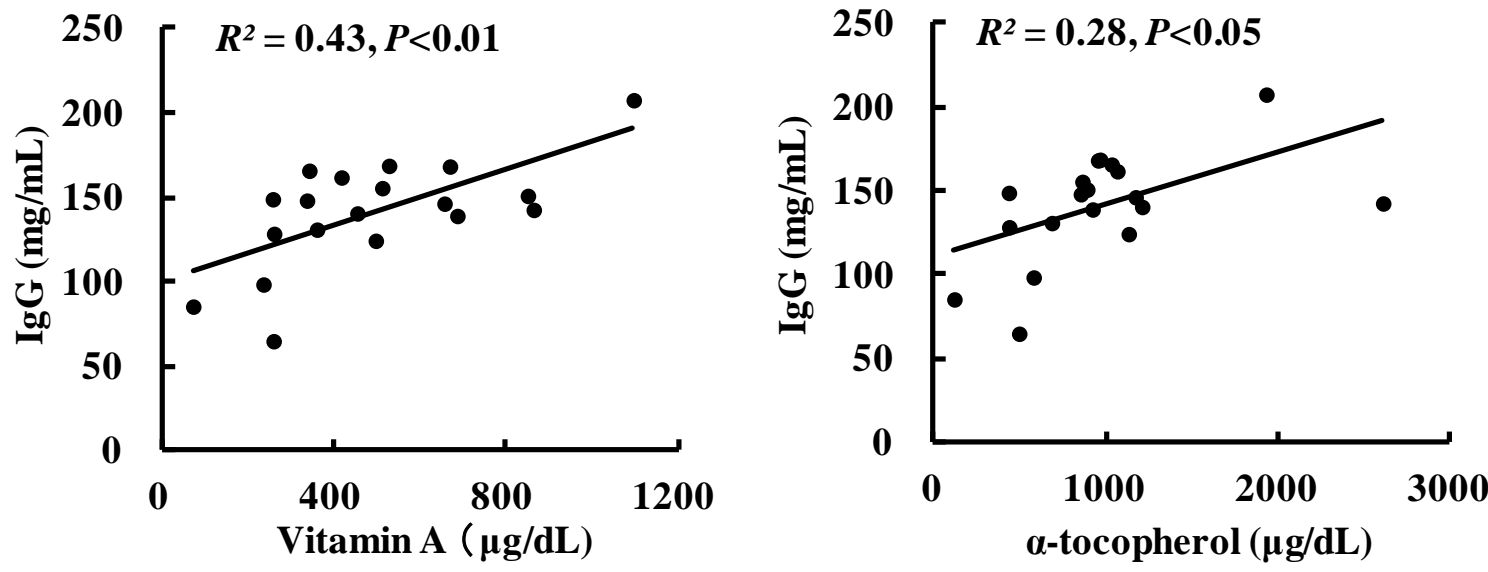

$4 \quad$ Figure 1 

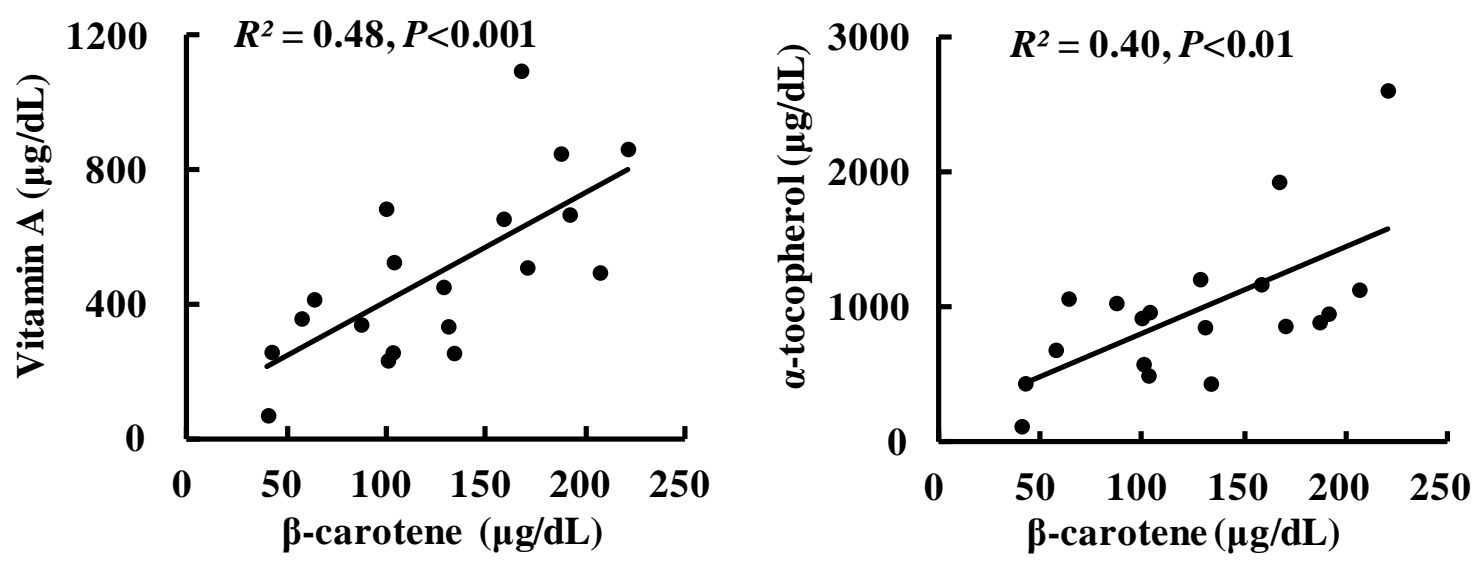

2
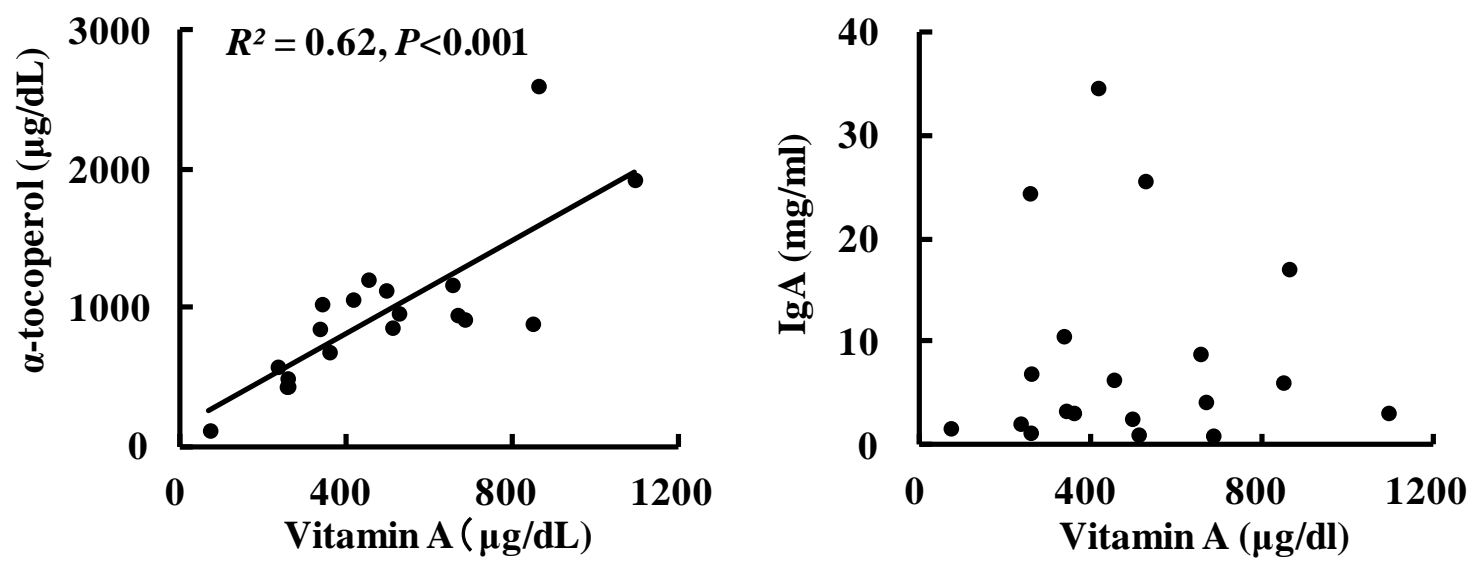

$4 \quad$ Figure 2 